\title{
Perceptions of Indonesian Students on the Role of Teachers in Offline and Online Learning During the Covid-19 Pandemic Period
}

\author{
Alhamuddin*, Rony Sandra Yofa Zebua \\ Universitas Islam Bandung, West Java Indonesia \\ *Corresponding Author. Email: alhamuddinpalembang@gmail.com
}

\begin{abstract}
This study aimed to analyze student perceptions regarding the role of teachers in classroom learning compared to online learning during the Covid-19 pandemic by applying a quantitative approach with a survey method. Population in this study was students throughout Indonesia who were actively learning during the Covid-19 pandemic. The research used Cluster Sampling technique by distributing online forms to students studying at home in all provinces in Indonesia, from Aceh to Papua; while sampling was conducted by random system. Chi square data analysis was carried out to analyze the close relationship between two variables that had nominal data. The results showed that almost all respondents (683 students or $93.8 \%$ of them) preferred face-toface learning with teachers, while a small portion of 45 respondents $(6.2 \%)$ liked face-to-screen learning (online). Out of 728 respondents, 647 students $(88.9 \%)$ thought that the teacher's role could not be replaced by technology, and 81 students $(11.1 \%)$ thought that the teacher's role could be replaced by technology. Thus, it can be concluded that most students in Indonesia still preferred face-to-face learning in class. Inequality in the distribution of learning resources such as internet network and teacher competence became a major problem in online learning, especially for students who lived in rural and disadvantaged areas.
\end{abstract}

\section{Article History}

Received: 18-06-2021

Revised: 27-09-2021

Accepted: 25-10-2021

Published: 11-12-2021

\section{Key Words:}

Instruction, Teacher,

Online, Offline,

Technology

How to Cite: Alhamuddin, A., \& Zebua, R. (2021). Perceptions of Indonesian Students on the Role of Teachers in Offline and Online Learning During the Covid-19 Pandemic Period. Jurnal Kependidikan: Jurnal Hasil Penelitian dan Kajian Kepustakaan di Bidang Pendidikan, Pengajaran dan Pembelajaran, 7(4), 834-844. doi:https://doi.org/10.33394/jk.v7i4.3881

dc. https://doi.org/10.33394/jk.v7i4.3881

This is an open-access article under the CC-BY-SA License.

\section{Introduction}

The Covid-19 has become a worldwide epidemic. Almost all countries in the world have been affected by the epidemic. Therefore, all activities are carried out from home so that the spread of the epidemic can be contained. One of the activities carried out at home is that students learned from home through various online media. Much research has been done regarding the benefits of online learning for both students and teachers (Ally, 2004; Moore et al., 2011).

The presence of the teacher in the learning process will be different than the presence of the teacher in the classroom. Time is limited by quota and network, so communication is not free like offline learning. Teachers play role as a model in classroom learning (Makhanya, 2002, p. 142) (Makhanya, 2002). The teacher acts as an educator as well as a teacher for students (Alhamuddin \& Bukhori, 2016). Heyneman and Loxley (1983) conducted research in 29 developed and developing countries on variables affecting student success in learning. The results of the research show that in both developed and developing countries, the teacher variable has a significant influence on student success in the learning process compared to the variables of management, infrastructure, and student learning time. Thus, teachers have a very important role in advancing the education of a nation (Enke et al., 2018; Gleason, 2018; Gonzalez, Julia, Wagenaar, 2006; Kiany, Mahdavy, \& Samar, 2011; Parker, 2010). The 
presence of teachers in the classroom as educators, teachers, learning resources, facilitators, motivators, advisors, and evaluators certainly cannot be done freely when teaching process is conducted via online model.

Indonesia is a country having 34 provinces with various conditions of leading, developed and underdeveloped areas. The implementation of these online learning activities is also very varied. According to several studies, (i) variations between teachers in terms of teaching abilities and learning methods, (ii) variations between schools in terms of financial support, and (iii) variations between home environments related to the socio-economic conditions of parents and the availability of supporting facilities play a role in supporting or hindering implementation of online learning (Ministry of Education and Culture, 2020 cited as Alifia et al., 2020; Arsendy, Sukoco, \& Purba, 2020). Based on the explanation above, this study aimed to analyze students' perceptions regarding online and offline learning, either the students prefer online learning or face-to-face meeting with teachers in class face-to-face.

\section{Research Method}

This study used a quantitative approach and survey methods. The population of this study was the students actively learning during the Covid-19 pandemic throughout Indonesia. This study used the Cluster Sampling (Area Sampling) technique, which was a sampling technique to determine the sample if the object studied or the data source was very broad, for instances, people of a country, province and district. The regions in Indonesia that were sampled in this study consisted of: 1) Sumatera Island (Aceh, Lampung, Bangka Belitung, Jambi, North Sumatra, West Sumatra, Riau and South Sumatra), 2) Java Island (Banten, DKI Jakarta, West Java), Central Java, East Java, and the Special Region of Yogyakarata), 3) Kalimantan Island (West Kalimantan, South Kalimantan, and East Kalimantan), 4) Sulawesi Island (South Sulawesi and Southeast Sulawesi), 5) West Nusa Tenggara, and 6) Maluku.

Data collection in this study was carried out by distributing online forms, namely google forms, to students studying at home. The forms were distributed in all provinces in Indonesia, from Aceh to Papua. Samples were taken randomly. The analytical technique in this study used Chi square to analyze the close relationship between two variables that had nominal data.

\section{Results and Discussion}

This research was conducted by distributing google forms to all students in Indonesia from Aceh to Papua randomly. The following is a presentation of the data obtained

Table 1. Frequency Distribution of Respondents by Gender

\begin{tabular}{ccc}
\hline Gender & Frequency & Percentage (\%) \\
\hline Male & 304 & 41,8 \\
Female & 424 & 58,2 \\
\hline Total & 728 & 100
\end{tabular}

Based on Table 1, it can be seen that from 728 respondents, most of the respondents were female, namely as many as 424 respondents (58.2\%), and almost half of 304 respondents (41.8\%) were male. Table 2 as the following reveals the respondents data based on place of residence/island.

Table 2. Frequency Distribution of Respondents by Place of Residency/Island

\begin{tabular}{ccc}
\hline Island & Frequency & Percentage (\%) \\
\hline Sumatera & 102 & 14,0 \\
Java & 569 & 78,2 \\
Kalimantan & 4 & 0,5 \\
\hline
\end{tabular}




\begin{tabular}{ccc}
\hline Sulawesi & 4 & 0,5 \\
West Nusa Tenggara & 48 & 6,6 \\
Maluku & 1 & 0,1 \\
\hline Total & 728 & 100
\end{tabular}

Based on Table 2, it can be seen that from 728 respondents, almost all of them lived on the island of Java, namely as many as 569 respondents $(78.2 \%)$, and a small portion of 1 respondent $(0.1 \%)$ lived on the island of Maluku. Table 3 as the following showed the respondents data based on preferred learning.

Table 3. Frequency Distribution of Respondents Based on Preferred Learning

\begin{tabular}{ccc}
\hline Learning & Frequency & Percentage (\%) \\
\hline Face to face with Teacher & 683 & 93,8 \\
Online & 45 & 6,2 \\
\hline Total & 728 & 100
\end{tabular}

Based on Table 3, it can be seen that from 728 respondents, almost all respondents preferred face-to-face learning with teachers, namely as many as 683 respondents (93.8\%), and a small portion of 45 respondents (6.2\%) preferred online learning. Table 4 as the following shows the perception of respondents about either teachers' roles can be replaced with technology or not.

Table 4. Frequency Distribution of Respondents based on Perception of Teacher's Role Can be Replaced with Technology

\begin{tabular}{ccc}
\hline $\begin{array}{c}\text { Teacher's Role Can Be } \\
\text { Replaced with Technology }\end{array}$ & Frequency & Percentage (\%) \\
\hline Yes & 81 & 11,1 \\
No & 647 & 88,9 \\
\hline Total & 728 & 100 \\
\hline
\end{tabular}

Based on Table 4, it can be seen that from 728 respondents, almost all of the respondents thought that the role of the teacher could not be replaced by technology, namely as many as 647 respondents $(88.9 \%)$, and a small proportion of 81 respondents $(11.1 \%)$ thought that the role of the teacher could be replaced by technology.

The Relationship between Gender and Learning Preference (Perception of Teacher Roles Can be Replaced with Technology)

Table 5. Frequency Distribution of Respondents Based on the Relationship between Gender and Preferred Learning

\begin{tabular}{|c|c|c|c|c|c|c|c|}
\hline \multirow{3}{*}{ Gender } & \multicolumn{4}{|c|}{ Preferred Learning } & \multirow{3}{*}{ Quantity } & \multirow{3}{*}{$\%$} & \multirow{3}{*}{ p-value } \\
\hline & \multicolumn{2}{|c|}{ Face to Face } & \multicolumn{2}{|c|}{ Online } & & & \\
\hline & $\mathbf{N}$ & $\%$ & $\mathbf{N}$ & $\%$ & & & \\
\hline Male & 285 & $39,1 \%$ & 19 & $2,6 \%$ & 304 & $41,8 \%$ & \\
\hline Female & 398 & $54,7 \%$ & 26 & $3,6 \%$ & 424 & $58,2 \%$ & 0,948 \\
\hline Total & 683 & $93,8 \%$ & 45 & $6,2 \%$ & 728 & $100 \%$ & \\
\hline
\end{tabular}

Table 5 above shows that from 728 respondents, it can be seen that almost half of male preferred face-to-face learning with teachers as many as 285 respondents $(39.1 \%)$ and a small proportion of 19 respondents (2.6\%) like online learning. Meanwhile, female mostly liked face-to-face learning with teachers as many as 398 respondents $(54.7 \%)$ and a small portion of 26 respondents (3.6\%) preferred online learning. In addition, based on the results of the Chi-Square calculation using SPSS, the p value of 0.948 with an alpha of 0.05 was obtained. The conclusion in this study is $\mathrm{p}$ value $(0.948)>(0.05)$, meaning that HO was 
accepted and $\mathrm{H} 1$ was rejected. This means that there was no relationship between gender and preferred learning, so that there was no difference between men and women in the selection of learning that students liked.

Table 6. Frequency Distribution of Respondents based on the Relationship between Gender and Perceptions of the Teacher's Role Can either be Replaced with Technology or Not

\begin{tabular}{|c|c|c|c|c|c|c|c|}
\hline \multirow{3}{*}{ Gender } & \multicolumn{4}{|c|}{$\begin{array}{c}\text { Teacher's Role Can be } \\
\text { Replaced with Technology }\end{array}$} & \multirow[t]{3}{*}{ Quantity } & \multirow[t]{3}{*}{$\%$} & \multirow{3}{*}{ p-value } \\
\hline & \multicolumn{2}{|c|}{ Yes } & \multicolumn{2}{|c|}{ No } & & & \\
\hline & $\mathbf{N}$ & $\%$ & $\mathbf{N}$ & $\%$ & & & \\
\hline Male & 36 & $4,9 \%$ & 268 & $\begin{array}{c}36,8 \\
\%\end{array}$ & 304 & $41,8 \%$ & \\
\hline Female & 45 & $6,2 \%$ & 379 & $\begin{array}{c}52,1 \\
\%\end{array}$ & 424 & $58,2 \%$ & 0,603 \\
\hline Total & 81 & $11,1 \%$ & 647 & $\begin{array}{c}88,9 \\
\%\end{array}$ & 728 & $100 \%$ & \\
\hline
\end{tabular}

Table 6 above shows that from 728 respondents, it can be seen that almost half of men thought that the teacher's role could not be replaced by technology, namely as many as 268 respondents $(36.8 \%)$ and a small portion of 36 respondents $(4.9 \%)$ thought that the role of teachers could be replaced by technology. Meanwhile, the majority of women considered that the role of the teacher could not be replaced by technology, namely as many as 379 respondents $(52.1 \%)$ and a small portion of 45 respondents $(6.2 \%)$ thought that the role of the teacher could be replaced by technology. In addition, based on the results of the Chi-Square calculation using SPSS, the p-value of 0.603 with an alpha of 0.05 was obtained. The conclusion in this study was p value (0.603) higher than 0.05 , meaning that $\mathrm{H} 0$ was accepted and $\mathrm{H} 1$ was rejected. This means that there was no relationship between gender and the perception of the teacher's role can be replaced with technology, so that there was no difference between men and women, regarding students' perceptions of the teacher's role could be replaced by technology.

The Relationship Between Residency and Learning Preference (the Perception of the Teacher's Role can be Replaced by Technology)

Table 7. Frequency Distribution of Respondents based on the Relationship between Residency and Learning Preference

\begin{tabular}{|c|c|c|c|c|c|c|c|}
\hline \multirow{3}{*}{ Island } & \multicolumn{4}{|c|}{ Preferred Learning } & \multirow{3}{*}{ Quantity } & \multirow{3}{*}{$\%$} & \multirow{3}{*}{ p-value } \\
\hline & \multicolumn{2}{|c|}{ Face to Face } & \multicolumn{2}{|c|}{ Online } & & & \\
\hline & $\mathbf{N}$ & $\%$ & $\mathbf{N}$ & $\%$ & & & \\
\hline Sumatera & 97 & $13,3 \%$ & 5 & $0,7 \%$ & 102 & $14,0 \%$ & \\
\hline Java & 534 & $73,4 \%$ & 35 & $4,8 \%$ & 569 & $78,2 \%$ & \\
\hline Kalimantan & 4 & $0,5 \%$ & 0 & $0,0 \%$ & 4 & $0,5 \%$ & \\
\hline Sulawesi & 3 & $0,4 \%$ & 1 & $0,1 \%$ & 4 & $0,5 \%$ & \\
\hline West Nusa & 44 & $6,0 \%$ & 4 & $0,5 \%$ & 48 & $6,6 \%$ & 0,632 \\
\hline Tenggara & & & & & & & \\
\hline Maluku & 1 & $0,1 \%$ & 0 & $0,0 \%$ & 1 & $0,1 \%$ & \\
\hline Total & 683 & $93,8 \%$ & 45 & $6,2 \%$ & 728 & $100 \%$ & \\
\hline
\end{tabular}

Source : $x^{2}$ test on SPSS 
Table 7 above shows that from 728 respondents, it can be seen that respondents living on the island of Sumatra preferred face-to-face learning with teachers, namely as many as 97 respondents $(13.3 \%)$ and 5 respondents $(0.7 \%)$ liked online learning. Respondents on the island of Java mostly liked face-to-face learning with teachers, namely as many as 534 respondents $(73.4 \%)$ and 35 respondents $(4.8 \%)$ preferred online learning. Respondents on the island of Kalimantan liked face-to-face learning with teachers, namely as many as 4 respondents $(0.5 \%)$ and none of them liked online learning. Respondents on the island of Sulawesi liked face-to-face learning with teachers, namely as many as 3 respondents $(0.4 \%)$ and 1 respondent liked online learning $(0.1 \%)$. Respondents on the island of West Nusa Tenggara liked face-to-face learning with teachers, namely as many as 44 respondents $(6 \%)$ and 4 respondents $(0.5 \%)$ preferred online learning. While respondents on the island of Maluku preferred face-to-face learning with teachers, namely as much as 1 respondent $(0.1 \%)$ and no one liked online learning.

In addition, based on the results of the Chi-Square calculation using SPSS, the p-value of 0.632 with an alpha of 0.05 was obtained. The conclusion in this study was p-value $(0.632)$ was more than 0.05 , meaning that $\mathrm{H} 0$ was accepted and $\mathrm{H} 1$ was rejected. This means that there was no relationship between residency and learning preference, so that it can be said that residency did not affect the choice of student-favored learning.

Table 8. Frequency Distribution of Respondents based on the Relationship between

Residency and Perception of the Teacher's Role Can be Replaced with Technology

\begin{tabular}{|c|c|c|c|c|c|c|c|}
\hline \multirow{3}{*}{ Island } & \multicolumn{4}{|c|}{$\begin{array}{c}\text { Teacher's Role Can Be Replaced } \\
\text { With Technology }\end{array}$} & \multirow[t]{3}{*}{ Quantity } & \multirow[t]{3}{*}{$\%$} & \multirow{3}{*}{ p-value } \\
\hline & \multicolumn{2}{|c|}{ Yes } & \multicolumn{2}{|c|}{ No } & & & \\
\hline & $\mathbf{N}$ & $\%$ & $\mathbf{N}$ & $\%$ & & & \\
\hline Sumatera & 11 & $1,5 \%$ & 91 & $12,5 \%$ & 102 & $14,0 \%$ & \\
\hline Java & 66 & $9,1 \%$ & 503 & $69,1 \%$ & 569 & $78,2 \%$ & \\
\hline Kalimantan & 0 & $0,0 \%$ & 4 & $0,5 \%$ & 4 & $0,5 \%$ & \\
\hline Sulawesi & 0 & $0,0 \%$ & 4 & $0,5 \%$ & 4 & $0,5 \%$ & 0896 \\
\hline West Nusa & 4 & $0,5 \%$ & 44 & $6,0 \%$ & 48 & $6,6 \%$ & 0,890 \\
\hline Tenggara & & & & & & & \\
\hline Maluku & 0 & $0,0 \%$ & 1 & $0,1 \%$ & 1 & $0,1 \%$ & \\
\hline Total & 81 & $11,1 \%$ & 647 & $88,9 \%$ & 728 & $100 \%$ & \\
\hline
\end{tabular}

Source: $x^{2}$ test on SPSS

Table 8 above shows that from 728 respondents, it can be seen that respondents who lived on the island of Sumatra thought that the teacher's role could not be replaced by technology, namely as many as 91 respondents $(36.8 \%)$ and 11 respondents thought that the teacher's role could be replaced by technology $(1.5 \%)$. Respondents in Java said that 503 respondents $(69.1 \%)$ could not replace the teacher's role with technology and 66 respondents $(9.1 \%)$ thought that the teacher's role could be replaced by technology. Respondents on the island of Kalimantan believed that the role of the teacher could not be replaced by technology, namely as many as 4 respondents $(0.5 \%)$ and no one believed that the role of the teacher could be replaced by technology. Respondents on the island of Sulawesi believed that the role of the teacher could not be replaced by technology, namely as many as 4 respondents $(0.5 \%)$ and no one thought that the role of the teacher could be replaced by technology. Respondents on the island of West Nusa Tenggara believed that the role of the teacher could not be replaced by technology, namely as many as 44 respondents $(6 \%)$ and 4 respondents thought that the role of the teacher could be replaced by technology $(0.5 \%)$. Meanwhile, 
respondents on the island of Maluku believed that the role of the teacher could not be replaced by technology, namely as much as 1 respondent $(0.1 \%)$ and no one thought that the role of the teacher could be replaced by technology. In addition, based on the results of the Chi-Square calculation using SPSS, the p-value of 0.896 with an alpha of 0.05 was obtained. The conclusion in this study suggested that p-value (0.896) was more than 0.05 , meaning that $\mathrm{H} 0$ was accepted and $\mathrm{H} 1$ was rejected. This means that there was no relationship between residency and the perception of the teacher's role could be replaced with technology. Therefore, it can be said that residency did not affect students' perceptions regarding the role of the teacher could be replaced by technology.

\section{Comparison of Face-to-face Learning Activities in Class and Online Learning}

Online learning has different characteristics from face-to-face learning in the classroom. The most basic difference between the two is related to social interaction and communication occuring between teachers, students and the surrounding environment (Hass \& Joseph, 2018; Wuensch, Aziz, Ozan, Kishore, \& Tabrizi, 2008, p. 524). The interaction occuring in online learning is very limited (Bowers \& Kumar, 2015; Cole, Shelley, \& Swartz, 2014) and it is difficult to provide the same quality of teaching as learning face-to-face in class (Wang et al., 2019).

A sense of social presence and attachment is not easy to manifest in online activities (Bowers \& Kumar, 2015), so that teachers cannot pay attention directly to the conditions, facial expressions and body language of students those which are feedback on learning activities that takes place, and vice versa (Wuensch et al., 2008). Therefore, teachers face obstacles in paying attention and understanding the level of student attention.

In addition, in online learning, communication requires greater ability and effort than direct learning (Cole et al., 2014). Class settings also cannot be done freely and require more expertise (Wang et al., 2019). The assessment process is also complicated by the geographical distance between teachers and students, thus requiring better skills for teachers to control the testing environment (Wuensch et al., 2008).

\section{Teacher's Role in Learning}

Teachers play an important role in all forms of the learning process (Forsström, 2019:379). Optimizing the teacher's role in learning activities will positively affect students' intention to learn (Xu, Chen, \& Chen, 2020: 3). The most basic role of the teacher is as a learning partner for students (Goodall, 2015; Shim, 2008; Smidt, 2014; Xhemajli, 2016 :), so that teachers are not only as a teacher but also as a mentor and educator.

Teachers are tasked with transferring knowledge (Alhamuddin \& Bukhori, 2016: 38; Makhaya, 2002: 142; Popper-Giveon \& Shayshon, 2016), providing accurate information (Van den Broeck, Demanet, \& Van Houtte, 2020: 8), as well as presenting teaching in a comfortable and interesting method (Moustafa , Ben-Zvi-Assaraf, \& Eshach, 2013, p. 419). Thus, the teacher also plays a role as an innovator with various new ideas that develop the learning process (Kocasarac, Taspinar, \& Karatas, 2019) (Kocasarac et al., 2019). At the same time, the teacher also acts as a facilitator (Ally, 2019: 304; Chumdari, Anitah, Budiyono, \& Suryani, 2018: 71; Demir, 2018; Robih, Suratman, \& Soesatyo, 2017: 6) who seeks appropriate learning resources and learning activities supporting the success of the learning process (Ally, 2019). Teachers are also coaches (Shim, 2008: 525), who transfer skills and life skills in practice (O'neil \& Hopkins, 2002)

Furthermore, the teacher acts as a guide (Gamal, 2020: 4), namely providing direction or advice (Rai, 2014: 31) and encouraging the development of student independence in a 
direction that is in accordance with educational goals (Moustafa et al., 2013: 419). As mentors, teachers also provide motivation that can encourage students to have passion and discipline in learning (Backfisch, Lachner, Hische, Loose, \& Scheiter, 2020; Chumdari et al., 2018: 71; Davion Johnson, 2017; Moustafa et al. , 2013 : 419). Then, the teacher acts as an educator (Popper-Giveon \& Shayshon, 2016) who trains students' morale (Jevtic, 2014: 69) or fosters it (Shim, 2008: 534) by transferring good grades (Özdilekler et al., 2018) and providing real examples to students (Gould-Yakovleva, McVee, \& Fronczak, 2020 : 315; Shim, 2008: 530) or role model (Gamal, 2020: 4; Lunenberg, Korthagen, \& Swennen, 2007 ), so that it becomes an inspiration to be imitated (Sammons et al., 2016). In each of these teacher roles, the teacher is an evaluator (McFadden \& Williams, 2020) and a corrector (Uysal \& Aydin, 2017) of the entire learning process and the results achieved.

Based on the description above, in any situation, the teacher must avoid any intervention that will interfere the interaction with students and gain their trust (Shim, 2008: 530). Along with the times and needs in this pandemic era, teachers have big challenges in carrying out their roles, especially in online learning. There are differences in characteristics between online learning and face-to-face learning directly in the classroom. Active learning strategies can transform the classroom atmosphere (Dabbagh, N., \& Bannan-Ritland, 2005;) (Dabbagh, N., \& Bannan-Ritland, 2005;). (Alhamuddin, 2018)

\section{Equitable Technology and Internet Network}

The implementation of online learning cannot be separated from the use of technology and internet network. However, currently there are still many regions in Indonesia that do not know or have an internet network in their area (Bakri, 2020; Kusuma, 2020; Yewun, 2020). There are areas that have internet network with weak connection, making it difficult for students to learn online (Alfarisi, 2020). Various problems related to the inadequate and uneven internet network conditions are experienced by some students in Indonesia.

Online learning activities also require appropriate and adequate technological devices. The technological devices used should provide comfort for students. However, the current conditions in Indonesia are very far from expectations in providing such comfort. There are still many students in Indonesia who do not have technological devices such as smartphones or personal computers or notebooks (Harusilo, 2020; Wilibardus, 2020). Thus, the state of the internet network and the availability or ownership of online technology devices in Indonesia are not evenly distributed (Siagian, 2020). This will make it difficult to organize online learning activities (Faqir, 2020). Thus, some students will find it difficult to get teaching, guidance and direction in whole or in part (Alhamuddin, 2016).

\section{Parents' Socio-Economic Factors}

Ownership of online technology devices needed in online learning is influenced by the socioeconomic conditions of the parents of students. In Indonesia, there is a fairly large socio-economic level gap (Mashabi, 2020) (Mashabi, 2020). Based on data from the Central Bureau of Statistics of the Republic of Indonesia submitted in March 2020, the number of poor people in Indonesia is around 26.42 million people (Ramadhani, 2020). This shows that at least around $10 \%$ of Indonesia's population will find it difficult to meet the needs of online tools. This figure is very likely to increase because the price of online technology devices is not cheap. Therefore, it is very reasonable if there are students who cannot afford it (Wilibardus, 2020). 


\section{Conclusion}

Based on the results of the research and discussion above, face-to-face learning with teachers in the classroom is an option for students compared to online learning. This is because the teacher's role directly cannot be replaced by technology, and moral values or the affective domain cannot be maximally carried out by teachers when learning online. In addition, the factors of parental support and various online learning facilities also cause inequality in this learning process. Students with limited support most feel the negative impact of stopping learning activities at school. In distance teaching practice, the diversity among teachers in terms of teaching abilities and teaching methods is influenced by several factors, such as access to the internet. Teachers in urban areas, both in Java and outside Java, tend to be more active in teaching.

\section{Recommendation}

The results of the study become a common thought, especially for policy makers to always pay attention to the condition of education in general, not only focusing on urban areas, but also underdeveloped areas. One of them is by equitable distribution of teacher competencies and the fulfillment of educational and learning support facilities, so that children in disadvantaged and outermost areas can also experience and quality education.

\section{References}

Alfarisi, M. (2020). Cari Sinyal, Mahasiswa Ini Rela Belajar di Tengah Sawah.

Alhamuddin. (2018). Abd Shamad al-Palimbani's Islamic education concept: Analysis of Kitab Hidayah al-Sālikin fi Suluk Māsālāk lil Muttāqin. Qudus International Journal of Islamic Studies, 6(1), 89-102. https://doi.org/10.21043/qijis.v6i1.3717

Alhamuddin, A. (2016). 4-Kurikulum Pendidikan Tinggi Keagamaan Islam Mutu Dan Relevansi. 3(April), 1-15.

Alhamuddin, \& Bukhori. (2016). The Effect of Multiple Intelligence-Based Instruction on Critical Thinking of Full Day Islamic Elementary Schools Students. Ta'dib, 21(1), 31-40. https://doi.org/10.19109/td.v21i1.590

Alifia, U., Barasa, A. R., Bima, L., Pramana, R. P., Revina, S., \& Tresnatri, F. A. (2020). Learning from Home: Portrait of Teaching and Learning Inequalities in Times of The Covid-19 Pandemic. Jakarta.

Ally, M. (2004). Theory and practice of online learning Second Edition. In T. Anderson (Ed.), Learners in a Changing Learning Landscape. AU Press,. https://doi.org/10.1007/978-1-4020-8299-3_8

Ally, M. (2019). Competency Profile of the Digital and Online Teacher in Future Education. International Review of Research in Open and Distance Learning, 20(2), 302-318. https://doi.org/10.19173/irrodl.v20i2.4206

Arsendy, S., Sukoco, G. A., \& Purba, R. E. (2020). Riset Dampak COVID-19: Potret Gap Akses Online 'Belajar dari Rumah' dari 4 Provinsi' [COVID-19 Impact Research: A Portrait of 'Learn from Home' Online Access Gap from 4 Provinces].

Backfisch, I., Lachner, A., Hische, C., Loose, F., \& Scheiter, K. (2020). Professional Knowledge or Motivation? Investigating the Role of Teachers' Expertise on the Quality of Technology-enhanced lesson plans. Learning and Instruction, 66, 1-13. https://doi.org/10.1016/j.learninstruc.2019.101300

Bakri. (2020). 74 SMA/SMK di Aceh tak Terjangkau Internet.

Bowers, J., \& Kumar, P. (2015). Students' Perceptions of Teaching and Social Presence : A Comparative Analysis of Face-to-Face and Online Learning Environments. 
International Journal of Web-Based Learning and Teaching Technologies, 10(1), 2744. https://doi.org/10.4018/ijwltt.2015010103

Chumdari, Anitah, S., Budiyono, \& Suryani, N. (2018). Inquiry-based Integrated Thematic Instruction On Character Education Of Primary School Students. International Journal of Education and Literacy Studies, 6(2), 69-78. https://doi.org/10.7575/aiac.ijels.v.6n.2p.69

Cole, M. T., Shelley, D. J., \& Swartz, L. B. (2014). Online Instruction, E-learning, and Student Satisfaction: A three Year Study. International Review of Research in Open and Distance Learning, 15(6), 111-131. https://doi.org/10.19173/irrodl.v15i6.1748

Dabbagh, N., \& Bannan-Ritland, B. (2005). Online learning: Concepts, strategies, and application. Upper Saddle River, NJ: Pearson/Merrill/Prentice Hall.

Davion Johnson. (2017). The Role of Teachers in Motivating Students to Learn. BU Journal of Graduate Studies in Education, 9(1), 46-49.

Demir, Y. (2018). A Meta- summary of the Research on Metaphors Regarding Turkish EFL Teachers' Roles. Advances in Language and Literary Studies, 9(2), 65-77. https://doi.org/10.7575/aiac.alls.v.9n.2p.65

Enke, J., Glass, R., Kreß, A., Hambach, J., Tisch, M., \& Metternich, J. (2018). Industrie 4.0 Competencies for a modern production system: A curriculum for Learning Factories. Procedia Manufacturing, 23(2017), 267-272. https://doi.org/10.1016/j.promfg.2018.04.028

Faqir, A. Al. (2020). Akses Internet Tak Merata Jadi Kendala Penerapan Belajar dari Rumah di Tengah Pandemi.

Forsström, S. E. (2019). Role of Teachers in Students' Mathematics Learning Processes Based on Robotics Integration. Learning, Culture and Social Interaction, 21, 378389. https://doi.org/10.1016/j.lcsi.2019.04.005

Gamal, M. A. (2020). Teaching Islam in an International School: A Bourdieusian Analysis. Religions, 11(7), 1-15. https://doi.org/10.3390/rel11070338

Gleason, N. W. (2018). Higher Education in the Era of the Fourth Industrial Revolution. In Higher Education in the Era of the Fourth Industrial Revolution. https://doi.org/10.1007/978-981-13-0194-0

Gonzalez, Julia, Wagenaar, R. (2006). Reference Points for the Design and Delivery of Degree Programmes in Teacher Education. In Tuning Educational Structures in Europe.

Goodall, J. (2015). Parents and Teachers as Partners in Education. International Encyclopedia of the Social \& Behavioral Sciences: Second Edition, 16, 499-502. https://doi.org/10.1016/B978-0-08-097086-8.92083-X

Gould-Yakovleva, O., McVee, M., \& Fronczak, D. (2020). "Ready-Ready" to Teach: The Telling Case of a Reflective Teacher-Practitioner. The Qualitative Report, 25(2), 306319.

Harususilo, Y. E. (2020). Tak Mampu Beli HP, Rafika Harus Menumpang demi Bisa Belajar Online.

Hass, A., \& Joseph, M. (2018). Investigating Different Options in Course Delivery Traditional vs Online: is There Another Option? International Journal of Information and Learning Technology, 35(4), 230-239. https://doi.org/10.1108/IJILT-09-20170096

Heyneman, S. P., \& Loxley, W. A. (1983). The effect of primary-school quality on academic achievement across twenty-nine high- and low-income countries. American Journal of Sociology, 88(6), 1162-1194. https://doi.org/10.1086/227799 
Jevtic, B. (2014). Teachers' Pedagogical Actions Affecting The Moral Development of Personality. Problems of Education In the 21 st Century, 58, 67-81.

Kiany, G. R., Mahdavy, B., \& Samar, R. G. (2011). Towards a Harmonized Foreign Language Education Program in Iran: National Policies and English Achievement. Literacy Information and Computer Education Journal, 2(3), 462-469. https://doi.org/10.20533/licej.2040.2589.2011.0064

Kocasarac, H., Taspinar, M., \& Karatas, H. (2019). Perceptions of School Principals Working at Science and Social Sciences High Schools on the Characteristics of Innovative Teachers. TOJET: The Turkish Online Journal of Educational Technology, 18(3), 70-88.

Kusuma, F. (2020). Pemerintah Harus Tingkatkan Pemerataan Jaringan Internet Jelang Pilkada Serentak.

Lunenberg, M., Korthagen, F., \& Swennen, A. (2007). The teacher educator as a role model. Teaching and Teacher Education, 23(5), 586-601. https://doi.org/10.1016/j.tate.2006.11.001

Makhanya, M. S. (2002). What do Teachers do? Q qualitative Analysis of the Role of the Teacher. Systemic Practice and Action Research, 15(2), 123-144. https://doi.org/10.1023/A:1015240524597

Mashabi, S. (2020). PP Muhammadiyah: Kesenjangan Ekonomi Jadi Persoalan Serius.

McFadden, A., \& Williams, K. E. (2020). Teachers as Evaluators: Results from a Systematic Literature Review. Studies in Educational Evaluation, 64, 1-17. https://doi.org/10.1016/j.stueduc.2019.100830

Moore, J. L., Dickson-Deane, C., \& Galyen, K. (2011). E-Learning, online learning, and distance learning environments: Are they the same? Internet and Higher Education, 14(2), 129-135. https://doi.org/10.1016/j.iheduc.2010.10.001

Moustafa, A., Ben-Zvi-Assaraf, O., \& Eshach, H. (2013). Do Junior High School Students Perceive Their Learning Environment as Constructivist? Journal of Science Education and Technology, 22(4), 418-431. https://doi.org/10.1007/s10956-0129403-y

O'neil, D. A., \& Hopkins, M. M. (2002). The Teacher as Coach Approach: Pedagogical Choices for Management Educators. Journal of Management Education, 26(4), 402414. https://doi.org/10.1177/105256290202600406

Özdilekler, M. A., Altınay, F., Altınay, Z., \& Dağlı, G. (2018). An Evaluation of ClassTeachers' Roles in Transferring Values. Quality and Quantity, 52(2), 1043-1058. https://doi.org/10.1007/s11135-017-0556-X

Parker, J. (2010). Competencies for interdisciplinarity in higher education. International Journal of Sustainability in Higher Education, 11(4), 325-338. https://doi.org/10.1108/14676371011077559

Popper-Giveon, A., \& Shayshon, B. (2016). Educator Versus Subject Matter Teacher: The Conflict Between Two Sub-Identities in Becoming a Teacher. Teachers and Teaching: Theory and Practice, 23(5), 1-17. https://doi.org/10.1080/13540602.2016.1218841

Rai, R. (2014). Inculcation of values: A necessity today. International Journal of Educational Research and Technology, 5(1), 30-32.

Ramadhani, P. I. (2020). Penduduk Miskin Indonesia Naik Jadi 26,42 Juta Orang di Maret 2020.

Robih, W., Suratman, B., \& Soesatyo, Y. (2017). The Effects of Self-efficacy, The Role of Teacher, Parents Participation to Studentâs Learning Motivation At Vocational High 
School North Surabaya. Journal of Economics and Economic Education Research, 18(2), 1-9.

Sammons, P., Lindorff, A. M., Ortega, L., \& Kington, A. (2016). Inspiring Teaching: Learning from Exemplary Practitioners. Journal of Professional Capital and Community, 1(2), 124-144. https://doi.org/10.1108/jpcc-09-2015-0005

Shim, S. H. (2008). A Philosophical Investigation of the Role of Teachers: A Synthesis of Plato, Confucius, Buber, and Freire. Teaching and Teacher Education, 24(3), 515535. https://doi.org/10.1016/j.tate.2007.09.014

Siagian, K. (2020). Kesenjangan Konektivitas di Pembelajaran Jarak Jauh Indonesia.

Smidt, S. (2014). Introducing Freire: A Guide for Students, Teachers and Practitioners. London: Routledge.

Uysal, N. D., \& Aydin, S. (2017). Foreign Language Teachers' Perceptions of Error Correction in Speaking Classes: A Qualitative Study. Qualitative Report, 22(1), 123135.

Van den Broeck, L., Demanet, J., \& Van Houtte, M. (2020). The Forgotten Role of Teachers in Students' Educational Aspirations. School Composition Effects and the Buffering Capacity of Teachers' Expectations Culture. Teaching and Teacher Education, 90, 111. https://doi.org/10.1016/j.tate.2020.103015

Wang, C., Hsu, H. K., Bonem, E. M., Moss, J. D., Yu, S., Nelson, D. B., \& Levesque-bristol, C. (2019). Need Satisfaction and Need Dissatisfaction: A Comparative Study of Online and Face-to-Face Learning Contexts. Computers in Human Behavior, 95, 114125. https://doi.org/10.1016/j.chb.2019.01.034

Wilibardus, D. (2020). Nestapa Pelajar NTT, Hidup Sebatang Kara dan Tak Punya HP untuk Belajar Daring.

Wuensch, K. L., Aziz, S., Ozan, E., Kishore, M., \& Tabrizi, M. H. N. (2008). Pedagogical Characteristics of Online and Face-to-Face Classes. International Journal on ELearning, 7(3), 523-532.

Xhemajli, A. (2016). The Role Of The Teacher In Interactive Teaching. International Journal of Cognitive Research in Science, Engineering and Education, 4(1), 31-37. https://doi.org/10.5937/IJCRSEE1601031X

Xu, B., Chen, N. S., \& Chen, G. (2020). Effects of Teacher Role on Student Engagement in WeChat-Based Online Discussion Learning. Computers and Education, 157, 1-11. https://doi.org/10.1016/j.compedu.2020.103956

Yewun, M. F. (2020). Pelajar Pedalaman Papua Tidak Menikmat Internet Gratis. 